\title{
SISTEM INFORMASI MANAJEMEN AKADEMIK DAN KOMPETENSI GURU UNTUK MENINGKATKAN MUTU HASIL PEMBELAJARAN
}

\author{
${ }^{1}$ Nada Shofa Lubis \\ STIT Islamic Village Tangerang \\ email. shofa.islamicvillageschool@gmail.com \\ ${ }^{2}$ Sufia Widi Kasetyaningsih \\ Universitas Duta Bangsa Surakarta \\ email. sufia_kasetyaningsih@yahoo.co.id
}

\begin{abstract}
Quality of learning outcomes in high school Islamic Village Tangerang has not led to the skills performed by the teacher and the guidance values, resulting in a negative image and persuasive in students as well as cause disappointment for every customer education, it arose because of inadequate teachers to master how to put together a lesson plan which arranges content, media technology, and value in every learning process. Formulation of the problem in this research are as follows: 1) how the academic management information systems influence against the quality of learning outcomes?, 2) how the influence of teacher competence against the quality of learning outcomes?, 3) How the influence of the system information management competency and academic teachers together against quality learning outcomes?. This research was carried out by using the eksplanatori method of nonexperimental. The population in this study was the High School teachers in Islamic Village Tangerang as many as 38 people. The technique of sampling in the census. The results showed a positive effect management information systems against the quality of the learning outcomes of $45.5 \%$ with $P$ value 0.000 or $\alpha<0,05$. Influential teacher competence positively against the quality of the learning outcomes of $62.6 \%$ with $P$ value 0.000 or $\alpha<0,05$. Management information system of teacher competence and positive effect toward the quality of the learning outcomes of $69.7 \%$ with $\mathrm{P}$ value 0.000 or $\alpha<0,05$
\end{abstract}

Keywords:. Management Information Systems; Competence; Quality Of Learning

\begin{abstract}
Abstrak : Mutu hasil pembelajaran di SMA Islamic Village Tangerang belum mengarah kepada keterampilan yang dilakukan oleh guru dan nilai-nilai bimbingan, sehingga menghasilkan image dan persuasif negatif pada siswa serta menimbulkan kekecewaan bagi setiap pelanggan pendidikan, hal tersebut timbul karena belum maksimalnya guru menguasai bagaimana menyusun rencana pelajaran yang mengemas isi, media teknologi, dan value dalam setiap proses pembelajaran. Rumusan masalah dalam penelitian ini adalah sebagai berikut: 1) bagaimana pengaruh sistem informasi manajemen akademik terhadap mutu hasil pembelajaran?, 2) bagaimana pengaruh kompetensi guru terhadap mutu hasil pembelajaran?, 3) Bagaimana pengaruh sistem informasi manajemen akademik dan kompetensi guru secara bersama-sama terhadap mutu hasil pembelajaran?.
\end{abstract}


ISTIGHNA, Vol. 2, No 2, Juli 2019 P-ISSN 1979-2824 E-ISSN 2655-8459

Homepage: http://e-journal.stit-islamic-village.ac.id/index.php/istighna

Nada Shofa Lubis dan Sufia Widi Kasetyaningsih Sistem Informasi Manajemen Akademik Dan Kompetensi Guru Untuk

Meningkatkan Mutu Hasil Pembelajaran

Penelitian ini dilaksanakan dengan menggunakan metode eksplanatori noneksperimental. Populasi dalam penelitian ini adalah guru-guru di SMA Islamic Village Tangerang sebanyak 38 orang. Teknik pengambilan sampel secara sensus. Hasil penelitian menunjukkan sistem informasi manajemen berpengaruh positif terhadap mutu hasil pembelajaran sebesar $45,5 \%$ dengan $P$ value $<\alpha$ atau 0,000 . Kompetensi guru berpengaruh positif terhadap mutu hasil pembelajaran sebesar $62,6 \%$ dengan $P$ value $<\alpha$ atau 0,000. Sistem informasi manajemen dan kompetensi guru berpengaruh positif terhadap mutu hasil pembelajaran sebesar $69,7 \%$ dengan $P$ value $<\alpha$ atau 0,000 .

Kata Kunci:. Sistem Informasi Manajemen, Kompetensi, Mutu Pembelajaran

\section{A. PENDAHULUAN}

Pendidikan sehingga aksesibilitas informasi dapat terserap dengan cepat dan tepat. Berkembangnya teknologi informasi manajemen dan komunikasi telah membuka kemungkinan-kemungkinan kegiatan yang sebelumnya sulit atau bahkan tak bisa dilakukan, saat ini dengan mudah bisa dilakukan. Misalnya kegiatan berkirim informasi ataupun kegiatan-kegiatan pendidikan secara online. Implementasi teknologi informasi dan komunikasi beserta komponen infra strukturnya benar-benar telah menandai terjadinya revolusi peradaban yang memungkinkan pekerjaan-pekerjaan dalam sistem organisasi dapat diselesaikan secara cepat, akurat, efektif, dan efisien.

Perkembangan teknologi informasi dan komunikasi (TIK) telah memberikan pengaruh terhadap dunia pendidikan khususnya dalam proses pembelajaran. Menurut Rosenberg dengan berkembangnya penggunaan TIK ada lima pergeseran dalam proses pembelajaran, yaitu: (1) dari pelatihan ke penampilan; (2) dari ruang kelas ke- dimana dan kapan saja; (3) dari kertas ke online; (4) fasilitas fisik ke fasilitas jaringan kerja, (5) dari waktu siklus ke waktu nyata. ${ }^{1}$

Dalam rangka mewujudkan proses pembelajaran yang berkualitas, pemerintah mengeluarkan Peraturan Pemerintah No 19 tahun 2005 tentang Standar Nasional Pendidikan (SNP) sebagai penjabaran lebih lanjut dari Undang-undang Sistem Pendidikan Nasional, yang di dalamnya memuat tentang standar proses. Dalam Bab I Ketentuan Umum SNP, yang dimaksud dengan standar proses adalah standar nasional pendidikan yang berkaitan dengan pelaksanaan pembelajaran pada satuan pendidikan untuk mencapai standar kompetensi lulusan. Bab IV Pasal 19 Ayat 1 SNP lebih jelas menerangkan bahwa proses pembelajaran pada satuan pendidikan diselenggarakan secara interaktif, inspiratif, menyenangkan, menantang, memotivasi peserta didik untuk berpartisipasi aktif, serta memberikan ruang yang cukup bagi prakarsa, kreativitas, dan kemampuan sesuai bakat, minat dan perkembangan fisik dan psikologis peserta didik.

Faktor lain yang mempengaruhi mutu hasil pembelajaran adalah kompetensi guru. Dimana peranan guru sangat menentukan dalam usaha peningkatan mutu pendidikan formal. Untuk itu guru sebagai agen pembelajaran dituntut untuk

\footnotetext{
${ }^{1}$ Rochaety, E 2008. Sistem Informasi Manajemen Pendidikan, Jakarta: PT. Bumi Aksara hal 172
} 
ISTIGHNA, Vol. 2, No 2, Juli 2019 P-ISSN 1979-2824 E-ISSN 2655-8459

Homepage: http://e-journal.stit-islamic-village.ac.id/index.php/istighna

Nada Shofa Lubis dan Sufia Widi Kasetyaningsih Sistem Informasi Manajemen Akademik Dan Kompetensi Guru Untuk Meningkatkan Mutu Hasil Pembelajaran

mampu menyelenggarakan proses pembelajaran dengan sebaik-baiknya, dalam kerangka mutu pelayanan pendidikan. Guru mempunyai fungsi dan peran yang sangat strategis dalam pembangunan bidang pendidikan, dan oleh karena itu perlu dikembangkan sebagai profesi yang bermartabat. Undang-Undang No.14 Tahun 2005 tentang Guru dan Dosen Pasal 4 menegaskan bahwa : "Guru sebagai agen pembelajaran berfungsi untuk meningkatkan mutu pendidikan nasional. Untuk dapat melaksanakan fungsinya dengan baik, guru wajib untuk memiliki syarat tertentu, salah satu diantaranya adalah kompetensi.

Mulyono menyebutkan bahwa konsep mutu pembelajaran mengandung lima rujukan, yaitu: 1) Kesesuaian meliputi indikator sebagai berikut: sepadan dengan karakteristik peserta didik, serasi dengan aspirasi masyarakat maupun perorangan, cocok dengan kebutuhan masyarakat, sesuai dengan kondisi lingkungan, selaras dengan tuntutan zaman, dan sesuai dengan teori, prinsip, dan / atau nilai baru dalam pendidikan.; 2) Pembelajaran yang bermutu juga harus mempunyai daya tarik yang kuat, indikatornya meliputi: kesempatan belajar yang tersebar dan karena itu mudah dicapai dan diikuti, isi pendidikan yang mudah dicerna karena telah diolah sedemikian rupa, kesempatan yang tersedia yang dapat diperoleh siapa saja pada setiap saat diperlukan, pesan yang diberikan pada saat dan peristiwa yang tepat, keterandalan yang tinggi, terutama karena kinerja lembaga dan lulusannya yang menonjol, keanekaragaman sumber baik yang dengan sengaja dikembangkan maupun yang sudah tersedia dan dapat dipilih serta dimanfaatkan untuk kepentingan belajar, dan suasana yang akrab hangat dan merangsang pembentukan kepribadian peserta didik; 3) Efektivitas pembelajaran sering kali diukur dengan tercapainya tujuan, atau dapat pula diartikan sebagai ketepatan dalam mengelola suatu situasi, atau "doing the right things", bersistem (sistematik), yaitu dilakukan secara teratur, konsisten atau berurutan melalui tahap perencanaan, pengembangan, pelaksanaan, penilaian dan penyempurnaan, sensitif terhadap kebutuhan akan tugas belajar dan kebutuhan pembelajar, kejelasan akan tujuan dan karena itu dapat dihimpun usaha untuk mencapainya, bertolak dari kemampuan atau kekuatan mereka yang bersangkutan (peserta didik, pendidik, masyarakat dan pemerintah); 4) Efisiensi pembelajaran dapat diartikan sebagai kesepadanan antara waktu, biaya, dan tenaga yang digunakan dengan hasil yang diperoleh atau dapat dikatakan sebagai mengerjakan sesuatu dengan benar. ${ }^{2}$

Sistem informasi manajemen akademik dan kompetensi guru diindikasikan mempunyai pengaruh yang sangat besar terhadap mutu hasil pembelajaran yang dicirikan dengan mutu mengajar guru, kelancaran layanan Proses Belajar Mengajar (PBM) sesuai jadwal, umpan balik yang diterima siswa mengenai pekerjaannya, layanan keseharian guru terhadap siswa, kepuasan siswa terhadap layanan mengajar yang diberikan guru, dan kenyamanan tempat belajar. Hal tersebut sangat menarik untuk diteliti sebagai salah satu solusi untuk memecahkan masalah yang berkaitan dengan mutu hasil pembelajaran

\footnotetext{
${ }^{2}$ Mulyono, E (2009). Standar Kompetensi dan Sertifikasi Guru, PT. Remaja Rosdakarya, Bandung
} hal 29 
ISTIGHNA, Vol. 2, No 2, Juli 2019 P-ISSN 1979-2824 E-ISSN 2655-8459

Homepage: http://e-journal.stit-islamic-village.ac.id/index.php/istighna

Nada Shofa Lubis dan Sufia Widi Kasetyaningsih Sistem Informasi Manajemen Akademik Dan Kompetensi Guru Untuk

Meningkatkan Mutu Hasil Pembelajaran

\section{B. METODE PENELITIAN}

Penelitian ini menggunakan jenis penelitian kuantitatif dengan pendekatan korelasional yang bersifat non eksperimental, yaitu penelitian atau penelaahan hubungan dua variabel atau lebih pada suatu situasi atau sekelompok subjek, yaitu untuk mencari hubungan sistem informasi manajemen dan kompetensi guru terhadap mutu hasil pembelajaran. Tujuan penelitian korelasional adalah untuk mendeteksi sejauh mana variasi-variasi pada suatu faktor berkaitan dengan variasi-variasi pada satu atau lebih faktor lain berdasarkan pada koefisien korelasi. Dikatakan bersifat non eksperimental, karena variabel bebas dalam penelitian ini tidak di bawah penelitian langsung peneliti. ${ }^{3}$ Analisis hubungan / pengaruh dari setiap variabel dapat digambarkan pada desain penelitian berikut.

Gambar B.1 Desain Penelitian

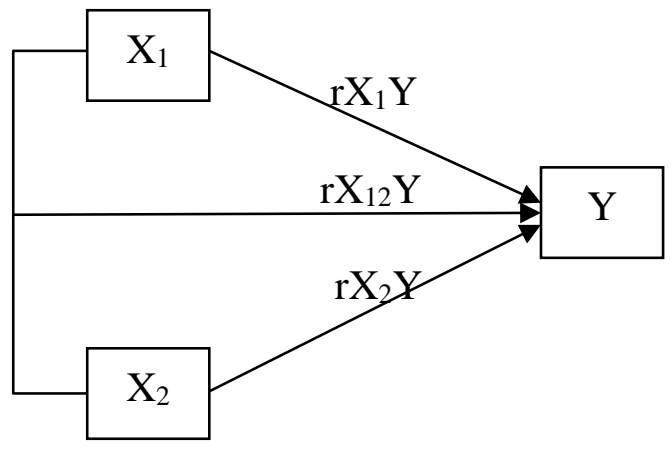

Keterangan :

$\mathrm{rX}_{1} \mathrm{Y}=$ Koefisien korelasi antara $\mathrm{X}_{1}$ dengan $\mathrm{Y}$

$\mathrm{rX}_{2} \mathrm{Y}=$ Koefisien korelasi antara $\mathrm{X}_{2}$ dengan $\mathrm{Y}$

$\mathrm{rX}_{12} \mathrm{Y}=$ Koefisien korelasi antara $\mathrm{X}_{1}$ dan $\mathrm{X}_{2}$ bersama sama terhadap $\mathrm{Y}$

Populasi dalam penelitian ini adalah guru-guru SMA Islamic Village sebanyak 38 orang. Sampel dalam penelitian ini ditetapkan dengan menggunakan teknik sampling jenuh atau sensus yaitu menjadikan semua anggota populasi sebagai sampel penelitian. Dengan demikian jumlah sampel yang diteliti sebanyak 38 orang.

Untuk memperoleh data yang diperlukan dalam penelitian ini diperlukan instrumen pengumpul data yaitu angket/kuesioner dengan terlebih dahulu dilakukan uji coba agar mencapai tingkat validitas dan reabilitas instrument. Analisis data menggunakan korelasi berganda untuk mengukur kontribusi antara sistem informasi manajemen terhadap variabel mutu hasil pembelajaran dan antara variabel kompetensi guru terhadap variabel mutu hasil pembelajaran dilakukan dengan menggunakan rumus korelasi Pearson Product Momen yang sebelumnya dilakukan uji asumsi klasik.

\footnotetext{
${ }^{3}$ Sugiyono, (2007). Metode Penelitian Pendidikan, CV Alfa Beta. Bandung hal 177
} 
ISTIGHNA, Vol. 2, No 2, Juli 2019 P-ISSN 1979-2824 E-ISSN 2655-8459

Homepage: http://e-journal.stit-islamic-village.ac.id/index.php/istighna

Nada Shofa Lubis dan Sufia Widi Kasetyaningsih Sistem Informasi Manajemen Akademik Dan Kompetensi Guru Untuk

Meningkatkan Mutu Hasil Pembelajaran

\section{HASIL DAN PEMBAHASAN}

\section{Pengaruh Sistem Informasi Manajemen terhadap Mutu Hasil Pembelajaran}

Uji statistik dilakukan dengan uji statistik parametrik yang mensyaratkan jenis-jenis data (skala pengukuran data) minimal berjenis interval, maka data berskala ordinal ditransformasikan ke dalam bentuk skala interval dengan menggunakan successive interval method seperti tercantum dalam lampiran dengan hasil sebagai berikut:

Tabel. C.1 Model Summary

Model Summary

\begin{tabular}{|l|r|r|r|r|}
\hline Model & R & R Square & Adjusted R Square & $\begin{array}{c}\text { Std. Error of the } \\
\text { Estimate }\end{array}$ \\
\hline 1 &, $675^{\mathrm{a}}$ &, 455 &, 448 & 7,29238 \\
\hline
\end{tabular}

a. Predictors: (Constant), SIM

Berdasarkan hasil di atas nilai $\mathrm{R}=0,675$ artinya sistem informasi manajemen memiliki hubungan yang kuat. Sedangkan nilai $R$ square $=0,455$ artinya sistem informasi manajemen berpengaruh positif terhadap mutu hasil pembelajaran sebesar $45,5 \%$. Dengan demikian semakin baik sistem informasi manajemen maka mutu hasil pembelajaran cenderung akan semakin baik.

Berdasarkan hasil perhitungan, diperoleh $\mathrm{Sig}=0,000$ sedangkan tingkat kesalahan sebesar 5\% atau $(\alpha=0,05)$ sehingga $P$ value $<\alpha$ atau $0,000<0,05$ maka $\mathrm{H}_{\mathrm{o}}$ ditolak dan $\mathrm{H}_{\mathrm{a}}$ diterima sehingga hipotesis diterima. Artinya terdapat pengaruh yang signifikan dari sistem informasi manajemen terhadap mutu hasil pembelajaran SMA Islamic Village Tangerang, sehingga hipotesis teruji kebenarannya.

Berdasarkan hasil penelitian diketahui bahwa sistem informasi manajemen SMA Islamic Village Tangerang cukup baik pada indikator dengan skor tertinggi adalah peraturan akademik mengenai "Peraturan akademik diputuskan oleh rapat dewan pendidik dan ditetapkan oleh kepala sekolah, hal ini sangat baik karena peraturan akademik harus diputuskan dalam rapat dewan pendidik.

Akademik adalah semua yang berkaitan dengan pendidikan dan pengembangannya yang bersifat ilmiah, akademik bisa berupa ilmu pengetahuan yang dipelajari dalam suatu instansi pendidikan. Akademik adalah pendidikan atau proses belajar mengajar. Akademik itu sendiri jika dilihat dari latar belakang terminologis adalah sebuah keadaan dimana orang-orang bisa menyampaikan dan menerima gagasan, pemikiran, atau ilmu pengetahuan sekaligus melakukan pengujian terhadapnya secara jujur, terbuka, dan leluasa.

Perkembangan teknologi yang semangkin pesat menjadi peranan penting dalam perkembangan organisasi atau lembaga. Semua organisasi atau lembaga dalam pengembangannya memerlukan informasi agar dapat memaksimalkan pengambilan keputusan baik yang bersifat operasional maupun yang bersifat strategis untuk semua masalah disetiap fungsi manajemen. Diperlukan kecepatan dan ketepatan informasi ketika berbagai masalah yang tingkat kompleksitasnya perlu diolah agar bisa mendapatkan solusi yang diperlukan secara efektif, efisien dan sistemik bagi setiap masalah. Seperti yang pada 
ISTIGHNA, Vol. 2, No 2, Juli 2019 P-ISSN 1979-2824 E-ISSN 2655-8459

Homepage: http://e-journal.stit-islamic-village.ac.id/index.php/istighna

Nada Shofa Lubis dan Sufia Widi Kasetyaningsih Sistem Informasi Manajemen Akademik Dan Kompetensi Guru Untuk

Meningkatkan Mutu Hasil Pembelajaran

umumnya dipahami, peranan teknologi informasi diperlukan untuk mendapatkan informasi yang cepat dan tepat tersebut. Teknologi informasi juga mempunyai sebutan lain yaitu teknologi komputer, yang dikhususkan untuk pengolahan data menjadi informasi yang bermanfaat bagi sebuah lembaga atau organisasi.

Sedangkan indikator dengan nilai terendah adalah kurikulum 2013 mengenai "Kurikulum 2013 dikembangkan sesuai dengan kondisi sekolah, potensi atau karakteristik daerah, sosial budaya masyarakat setempat, dan peserta didik". Struktur kuikulum untuk peserta didik berkebutuhan khusus tunagrahita ini berdasarkan kompetensi lulusan, standar kompetensi kelompok mata pelajaran, dan standar kompetensi mata pelajaran. Kurikulum 2013 untuk anak berkebutuhan khusus dikembangkan pendekatan berbasis budaya yang diajarkan secara terintegrasi pada semua mata pelajaran. Tentu saja ini harus diperhatikan karena palaksanaan kurikulum pendidikan khususnya Kurikulum 2013 harus diterapkan sesuai dengan kondisi sekolah, potensi atau karakteristik daerah, sosial budaya masyarakat setempat, dan peserta didik

\section{Pengaruh Kompetensi Guru terhadap Mutu Hasil Pembelajaran}

Uji statistik dilakukan dengan uji statistik parametrik yang mensyaratkan jenis-jenis data (skala pengukuran data) minimal berjenis interval, maka data berskala ordinal ditransformasikan ke dalam bentuk skala interval dengan menggunakan successive interval method seperti tercantum dalam lampiran dengan hasil belajar:

Tabel. C.2 Model Summary

Model Summary

\begin{tabular}{|l|r|r|r|r|}
\hline Model & \multicolumn{1}{|c|}{$\mathrm{R}$} & R Square & \multicolumn{1}{|c|}{$\begin{array}{c}\text { Adjusted R } \\
\text { Square }\end{array}$} & Std. Error of the Estimate \\
\hline 1 &, $791^{\mathrm{a}}$ &, 626 &, 622 & 6,04098 \\
\hline
\end{tabular}

a. Predictors: (Constant), Kompetensi Guru

Berdasarkan hasil di atas nilai $\mathrm{R}=0,791$ artinya kompetensi guru memiliki hubungan yang sangat kuat. Sedangkan nilai $R$ square $=0,626$ artinya kompetensi guru berpengaruh positif terhadap mutu hasil pembelajaran sebesar 62,6\%. Dengan demikian semakin baik kompetensi guru maka mutu hasil pembelajaran cenderung akan semakin baik.

Berdasarkan hasil perhitungan, diperoleh $\mathrm{Sig}=0,000$ sedangkan tingkat kesalahan sebesar $5 \%$ atau $(\alpha=0,05)$ sehingga $P$ value $<\alpha$ atau $0,000<0,05$ maka $\mathrm{H}_{\mathrm{o}}$ ditolak dan $\mathrm{H}_{\mathrm{a}}$ diterima sehingga hipotesis diterima. Artinya terdapat pengaruh yang signifikan dari kompetensi guru terhadap mutu hasil pembelajaran SMA Islamic Village Tangerang, sehingga hipotesis teruji kebenarannya.

Hasil penelitian menunjukkan bahwa komptensi guru SMA Islamic Village Tangerang termasuk kategori baik dengan skor tertinggi adalah kompetensi kepribadian mengenai "Guru dapat memiliki rasa kasih sayang kepada peserta didik tanpa membeda-bedakan dan Guru dapat memiliki rasa bertanggung jawab yang kokoh dalam melaksanakan fungsinya sebagai guru dengan nilai skor, hal 
ini sangat baik karena Guru harus memiliki rasa kasih sayang kepada peserta didik tanpa membeda-bedakan dan memiliki rasa bertanggung jawab yang kokoh dalam melaksanakan fungsinya sebagai guru.

Kompetensi pada hakekatnya menggambarkan, pengetahuan, keterampilan, sikap, dan nilai-nilai yang harus dikuasai peserta didik dan direfleksikan dalam kebiasaan berpikir dan bertindak. Kompetensi menggambarkan kemampuan bertindak yang dilandasi ilmu pengetahuan, dimana hasil dari tindakan tersebut bermanfaat bagi dirinya dan bagi orang lain. implikasi kinerja guru SMA nonPLB dalam melaksanakan kegiatan pembelajaran bagi anak berkebutuhan khusus (ABK) tampak pada aktivitas yang dilakukan guru SMA dalam mendidik, membimbing, membina, mengajar dan melatih keterampilan anak berkebutuhan khusus di SMA Kota Denpasar. Hal tersebut nampak pada kemampuan mereka dalam mengorganisasikan materi pembelajaran, kemampuan mereka dalam menggunakan metode pembelajaran, kemampuan menggunakan alat-alat bantu pembelajaran, kemampuan menggingatkan siswa dalam pemanfaatan media pembelajaran, kemampuan mengelola kelas, menumbuhkan partisipasi siswa dalam pembelajaran serta kemampuan memantau kemajuan belajar dan melakukan penilaian. Kinerja guru SMA yang ditampilkan melalui perencanaan pembelajaran, sebagian besar guru mengembangkan Rencana Pelaksanaan Pembelajaran berdasarkan pada silabus untuk mengarahkan siswa dalam upaya mencapai kompetensi dasar. Dalam proses pelaksanaan pembelajaran di kelas, kemampuan guru SMA mampu mengelola kelas dengan baik. Secara garis besar terdiri dari guru mampu menciptakan suasana kelas dan kemampuan memanfaatkan kelas untuk mencapai tujuan pembelajaran dilakukan dengan baik. Suryobroto mengatakan bahwa; kelas yang efektif menunjukan bahwa pengelolaan kelas dapat berimplikasi pada tingkah laku dan hasil belajar siswa. Untuk itu guru-guru perlu membuat perencanaan pengelolaan dan pengajaran dengan suatu cara tertentu agar siswa dapat memahami materi sesuai dengan tujuan yang diharapkan. ${ }^{4}$

Sedangkan indikator dengan nilai terendah adalah kompetensi sosial mengenai "Guru mampu memahami berbagai faktor yang berpengaruh dalam menciptakan lingkungan belajar yang mendukung PBM" dengan nilai skor 282 . Tentu saja ini harus diperhatikan karena Guru harus mampu memahami berbagai faktor yang berpengaruh dalam menciptakan lingkungan belajar yang mendukung PBM.

3. Pengaruh Sistem informasi manajemen dan Kompetensi guru terhadap Mutu hasil pembelajaran

Pengaruh sistem informasi manajemen dan kompetensi guru terhadap mutu hasil pembelajaran dengan hasil perhitungan SPSS diperoleh data sebagai berikut:

4 Suryosubroto, 2006, Pendidikan Guru Berdasarkan Pendekatan Kompetensi, Jakarta, Bumi Aksara. 
ISTIGHNA, Vol. 2, No 2, Juli 2019 P-ISSN 1979-2824 E-ISSN 2655-8459

Homepage: http://e-journal.stit-islamic-village.ac.id/index.php/istighna

Nada Shofa Lubis dan Sufia Widi Kasetyaningsih Sistem Informasi Manajemen Akademik Dan Kompetensi Guru Untuk

Meningkatkan Mutu Hasil Pembelajaran

Tabel. C.3 Model Summary

Model Summary

\begin{tabular}{|l|r|r|r|r|}
\hline Model & \multicolumn{1}{|c|}{$\mathrm{R}$} & R Square & Adjusted R Square & $\begin{array}{c}\text { Std. Error of the } \\
\text { Estimate }\end{array}$ \\
\hline 1 &, $835^{\mathrm{a}}$ &, 697 &, 690 & 5,47170 \\
\hline
\end{tabular}

a. Predictors: (Constant), Kompetensi Guru, SIM

Berdasarkan hasil di atas nilai $\mathrm{R}=0,835$ artinya sistem informasi manajemen dan kompetensi guru memiliki hubungan yang sangat kuat dengan mutu hasil pembelajaran. Sedangkan nilai $R$ square $=0,697$ artinya sistem informasi manajemen dan kompetensi guru berpengaruh positif terhadap mutu hasil pembelajaran sebesar $69,7 \%$. Dengan demikian semakin baik sistem informasi manajemen dan kompetensi guru maka mutu hasil pembelajaran cenderung akan semakin baik.

Berdasarkan hasil perhitungan, diperoleh Sig $=0,000$ sedangkan tingkat kesalahan sebesar 5\% atau $(\alpha=0,05)$ sehingga $P$ value $<\alpha$ atau $0,000<0,05$ maka $\mathrm{H}_{\mathrm{o}}$ ditolak dan $\mathrm{H}_{\mathrm{a}}$ diterima sehingga hipotesis diterima. Artinya terdapat pengaruh yang signifikan dari sistem informasi manajemen dan kompetensi guru terhadap mutu hasil pembelajaran SMA Islamic Village Tangerang, sehingga hipotesis teruji kebenarannya.

Berdasarkan data pada Tabel di atas dapat digambarkan pengaruh sistem informasi manajemen (X1) dan Kompetensi guru (X2) terhadap mutu hasil pembelajaran (Y) sebagai berikut:

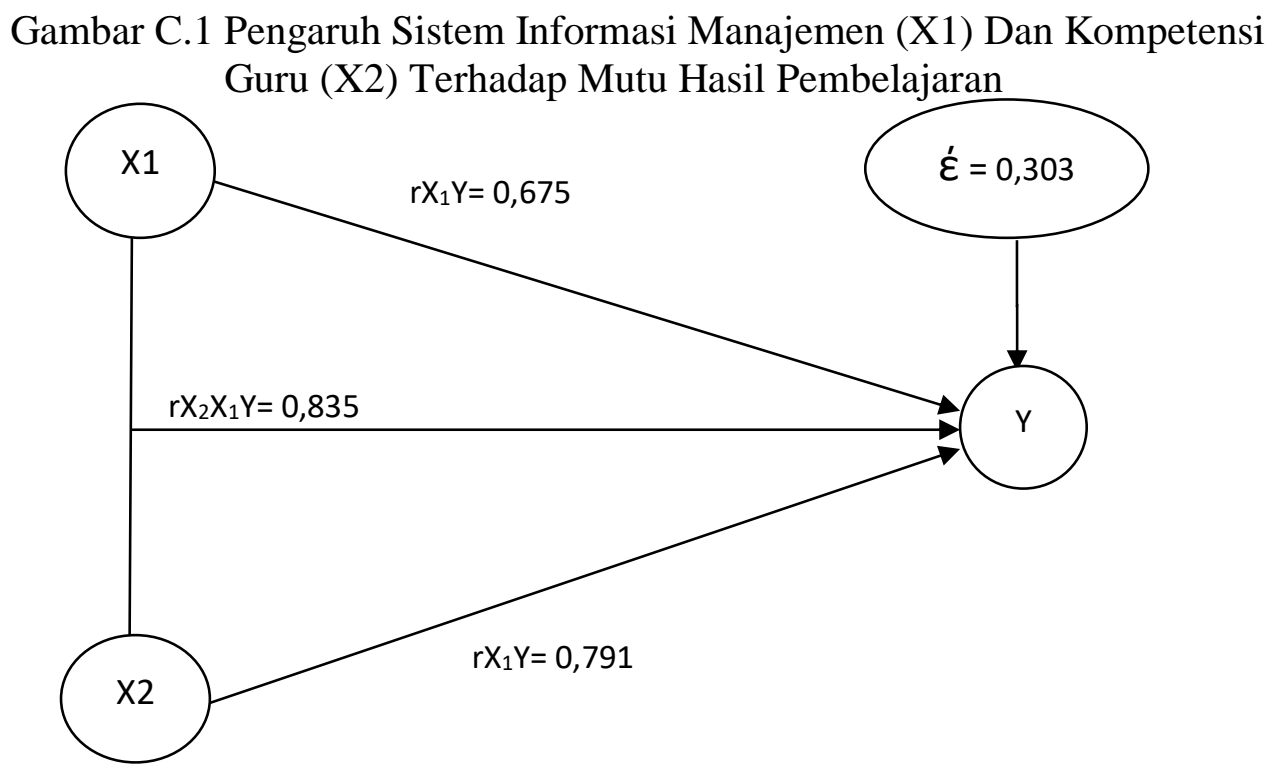

Perencanaan pembelajaran (intuctional desain), memperkirakan dan memproyeksikan tindakan atau aktivitas yang akan dilakukan pada saat pembelajaran. mengingat perencanaan sebagai proyeksi kegiatan, maka kedudukannya dalam sistem pembelajaran menjadi amat strategis. Anda dapat membayangkan apabila kegiatan pembelajaran sebagai upaya untuk merubah 
perilaku siswa, dan tidak melalui perencanaan yang matang, maka dapat dibayangkan akan seperti apa proses pembelajaran itu. Dampaknya terhadap proses dan hasil pembelajaran secara khusus dan penyidikan pada umumnya sulit diprediksi. Andai kita boleh membandingkan, dilihat dari resiko atau dampak yang dapat ditimbulkan, nampaknya lebih berbahaya pembelajaran yang tidak direncanakan dari pada membuat satu bangunan rumah. Keduanya beresiko, tapi karena pembelajaran langsung berhubungan dengan "pencetakan manusia", kerugian akan lebih patal dibandingkan dengan bentuk bangunan yang dihasilkan jika tanpa perencanaan. Sedangkan indikator dengan nilai terendah adalah hasil pembelajaran mengenai "Mampu menyimpulkan hasil penilaian secara jelas dan logis. Tentu saja ini harus diperhatikan karena hasil penilaian sebagai evaluasi dari kegiatan belajar mengajar yang harus jelas dan logis

Hasil penelitian menunjukkan terdapat pengaruh yang signifikan dari sistem informasi manajemen dan kompetensi guru terhadap mutu hasil pembelajaran SMA Islamic Village Tangerang. hasil penelitian ini sesuai dengan mendapat Gaol bahwa sistem informasi manajemen adalah "sebuah sistem informasi yang selain melakukan pengolahan transaksi yang sangat berguna untuk kepentingan organisasi, juga banyak memberikan dukungan informasi dan pengolahan untuk fungsi manajemen pengambilan keputusan". Dengan sistem informasi manajemen yang baik dan guru yang mempunyai potensi baik diharapkan akan meningkatkan mutu hasil pembelajaran. ${ }^{5}$

Sistem informasi manajemen akan berlangsung secara efektif dan efisien apabila didukung oleh sumber daya manusia yang profesional untuk mengoperasikan sekolah, dana yang cukup agar sekolah mampu menggaji staf sesuai dengan fungsinya, sarana prasarana yang memadai untuk mendukung proses belajar-mengajar, serta dukungan masyarakat (orang tua)yang tinggi. Adapun yang dapat menghambat penerapan sistem informasi manajemen yaitu terbatasnya sumber daya manusia (Brainware) yang terampil dalam pengelolaan sistem informasi, rendahnya kesadaran para pengelola sistem informasi dalam menyamakan komitmen kerja, fasilitas pendukung yang masih akan ditingkatkan kembali.

\section{KESIMPULAN}

Sistem Informasi Manajemen Akademik di SMA Islamic Village termasuk kategori baik indikator dengan skor tertinggi adalah peraturan akademik mengenai "Peraturan akademik diputuskan oleh rapat dewan pendidik dan ditetapkan oleh kepala sekolah dengan nilai skor sebesar 346. Sedangkan indikator dengan nilai terendah adalah kurikulum 2013 mengenai "Kurikulum 2013 dikembangkan sesuai dengan kondisi sekolah, potensi atau karakteristik daerah, sosial budaya masyarakat setempat, dan peserta didik" dengan nilai skor 155. Sistem Informasi Manajemen Akademik berpengaruh terhadap mutu hasil pembelajaran.

\footnotetext{
${ }^{5}$ Gaol, 2009, Total Quality Management in Education, London: Kogan Page Limited,
} 
ISTIGHNA, Vol. 2, No 2, Juli 2019 P-ISSN 1979-2824 E-ISSN 2655-8459

Homepage: http://e-journal.stit-islamic-village.ac.id/index.php/istighna

Nada Shofa Lubis dan Sufia Widi Kasetyaningsih Sistem Informasi Manajemen Akademik Dan Kompetensi Guru Untuk

Meningkatkan Mutu Hasil Pembelajaran

Kompetensi guru termasuk baik dengan indikator dengan skor tertinggi adalah kompetensi kepribadian mengenai "Guru dapat memiliki rasa kasih sayang kepada peserta didik tanpa membeda-bedakan dan Guru dapat memiliki rasa bertanggung jawab yang kokoh dalam melaksanakan fungsinya sebagai guru dengan nilai skor sebesar 328, hal ini sangat baik karena Guru harus memiliki rasa kasih sayang kepada peserta didik tanpa membeda-bedakan dan memiliki rasa bertanggung jawab yang kokoh dalam melaksanakan fungsinya sebagai guru. Sedangkan indikator dengan nilai terendah adalah kompetensi sosial mengenai "Guru mampu memahami berbagai faktor yang berpengaruh dalam menciptakan lingkungan belajar yang mendukung PBM" dengan nilai skor 282. Kompetensi guru berpengaruh kuat terhadap mutu hasil pembelajaran

Mutu hasil pembelajaran termasuk baik dengan indikator dengan skor tertinggi adalah Penyusunan Rencana Pelaksanaan Pembelajaran mengenai "Mampu menentukan strategi/ metode pembelajaran dengan nilai skor sebesar 337, hal ini sangat baik karena Penyusunan Rencana Pelaksanaan Pembelajaran sangat penting. Sedangkan indikator dengan nilai terendah adalah hasil pembelajaran mengenai "Mampu menyimpulkan hasil penilaian secara jelas dan logis" dengan nilai skor 219. Mutu hasil pembelajaran secara bersama-sama dipengaruhi oleh sistem informasi manajemen akademik dan kompetensi guru.

\section{REFERENSI}

Abdul Majid. (2005). Perencanaan Pembelajaran: Mengembangkan Standar Komepetensi Guru. Bandung: Remaja Rosdakarya.

Ariani, DW, (1999). Manajemen Kualitas, Yogyakarta:Universitas Atma Jaya.

Dedi Supriadi, (1999). Mengangkat Citra dan Martabat Guru, Yogyakarta, Adicita Karya Nusa.

Hamzah, (2007), Profesi Kependidikan. Jakarta. Bumi Aksara.

Kusnendi, (2007) . Validitas dan realibilitas model pengukuran, Program Magister Manajemen Pendidikan Progam Pascasarjana Universitas Galuh.

Maryono (http://suaraguru.wordpress.com.2009/10/05/peningkat_an-manajemenmutu-pembelajaran-di-sekolah/)

Moh. Uzer Usman, (2006). Menjadi Guru Profesional, Bandung, Remaja Rosdakarya.

Muhammad Surya, (2003). Psikologi Pembelajaran dan Pengajaran, Bandung: Yayasa Bhakti Winaya.

Muhibbin Syah, (1999). Psikologi Pendidikan, Bandung, Remaja Rosdakarya.

Mulyasa, E. (2003). Kurikulum Berbasis Kompetensi: Konsep, Karakteristik, dan Implementasi. Bandung: PT Remaja Rosdakarya

Mulyasa, E (2009). Standar Kompetensi dan Sertifikasi Guru, PT. Remaja Rosdakarya, Bandung.

Murdick, R.G., Ross, J.E (1997). Sistem Informasi untuk Manajemen Modern edisi ketiga (terjemahan J. Jamil). Jakarta. Erlangga. 
ISTIGHNA, Vol. 2, No 2, Juli 2019 P-ISSN 1979-2824 E-ISSN 2655-8459

Homepage: http://e-journal.stit-islamic-village.ac.id/index.php/istighna

Nada Shofa Lubis dan Sufia Widi Kasetyaningsih Sistem Informasi Manajemen Akademik Dan Kompetensi Guru Untuk

Meningkatkan Mutu Hasil Pembelajaran

Nana Sudjana, (1989). Pembinaan dan Pengembangan Kurikulum di Sekolah, Bandung, Sinar Baru.

Nana Syaodih S, (2001). Pengembangan Kurikulum Teori dan Praktek, Bnadung. Remaja Rosdakarya.

Oemar Hamalik, (2002). Pendidikan Guru Berdasarkan Pendekatan Kompetensi, Jakarta, Bumi Aksara.

Onong Ucheh Jana Effendi, (1989). Sistem Informasi Manajemen, Bandung: Bandar Maju.

Qomari, Anwar \& Sagala, Saiful. (2004). Profesi Jabatan Kependidikan dan Guru sebagai Upaya Menjamin Kualitas Pembelajaran. Jakarta: Uhamka Press.

Rochaety, E (2008). Sistem Informasi Manajemen Pendidikan, Jakarta: PT. Bumi Aksara.

Sallis, Edward, (1993). Total Quality Management in Education, London: Kogan Page Limited,

Siagian, S.P. (2001). Sistem Manajemen untuk Pengambilan Keputusan. Bandung. Remaja Rosdakarya.

Spencer, Lyle M, Signe M. Spencer, (1993), Competence at Work Models for Superior Performance. Canada: John Wiley \& Sons.

Sudrajat, (2009). Manajemen Pendidikan. 24 Oktober 2009. http//akhmadsudrajat.wordpress.com

Suharsimi Arikunto. (1998). Prosedur Penelitian : Suatu Pendekatan Praktek. Jakarta. Rineka Citra.

Sugiyono, (2007). Metode Penelitian Pendidikan, CV Alfa Beta. Bandung.

Tata Sutabri (2005). Sistem Informasi Manajemen, Yogyakarta. Andi.

T. Raka.Jono, (1984). Pedoman Umum Aat Penilaian Kemampuan Guru. Jakarta: Dirjen Pendidikan Tinggi Depdikbud. 